\title{
Good Cause Eviction and the Low Income Housing Tax Credit
}

\author{
Marc Jolin $\dagger$
}

Since its inception in 1986, the Low Income Housing Tax Credit ("LIHTC") ${ }^{1}$ has emerged as the federal government's largest affordable housing development program. ${ }^{2}$ The LIHTC was enacted as part of the shift toward localized and privatized federal social programs that occurred during the Reagan Administration. ${ }^{3}$ In some respects the LIHTC's design reflects these trends. The program is written into the tax code, rather than into the United States Housing Act of $1937 .{ }^{4}$ Primary administrative responsibility is assigned to state housing finance agencies, rather than to the U.S. Department of Housing and Urban Development ("HUD"), and the program offers an income tax credit that can be sold by developers to investors in exchange for needed construction capital, rather than a direct subsidy to lowincome housing developers.' Given these elements, one might have expected the LIHTC to embody another common feature of privatization, the reduction of federal regulation. This Comment argues, however, that this expectation is unsupported, at least with respect to federally mandated good cause eviction protection.

Good cause eviction protection is a well established feature of federal low-income housing programs created under the United States

$\dagger$ B.A. 1992, Swarthmore College; M.A. (Sociology) 1996, The University of Chicago; J.D. Candidate 2000, The University of Chicago.

1 The LIHTC was enacted as part of the Tax Reform Act of 1986 and was made permanent by the Omnibus Budget Reconciliation Act of 1993. See Tax Reform Act of 1986, Pub L No 99-514, 100 Stat 2085, codified at IRC \& 42 (1998); Omnibus Budget Reconciliation Act of 1993, Pub L No 103-66, 107 Stat 312.

2 See U.S. General Accounting Office (GAO), Tax Credits: Opportunities to Improve Oversight of the Low-Income Housing Program 2 (Mar 1997) (reporting that up to three billion dollars are made available annually through the program).

3 For a general discussion, see Shelby D. Green, The Public Housing Tenancy: Variations on the Common Law that Give Security of Tenure and Control, 43 Cath U L Rev 681, 683-84 (1994) (noting that "[t] he privatization movement achieved perhaps its greatest momentum during the [Reagan and Bush administrations]" and explaining how this movement affected lowincome housing policy). See also Michael H. Schill, Privatizing Federal Low Income Housing Assistance: The Case of Public Housing, 75 Cornell L Rev 878, 878-88 (1990) (discussing the academic debates surrounding privatization in the $1980 \mathrm{~s}$ and the implications of these debates for low-income housing policy). See also Part I.B.

4 Pub L No 93-383, 50 Stat 888 (1937), codified as amended at 42 USC $\$ \$ 1437$ et seq (1994 \& Supp 1996). This statute is the traditional source for federal low-income housing programs.

5 See Part I.C for a description of the structure of the LIHTC program. 
Housing Act and administered by HUD. Good cause eviction requires a landlord to renew a tenant's lease unless she can demonstrate a legally adequate reason why the tenant should be evicted. ${ }^{6}$ State landlord tenant laws, in contrast to federal housing programs, do not generally afford tenants this protection. ${ }^{7}$ Proponents of good cause eviction view it as a critical line of defense against discriminatory treatment, life-disruptions, and homelessness for low-income households. ${ }^{8}$ Critics, on the other hand, see the limit on landlords' ability to evict tenants as a significant cause of the "failure" of federal housing programs and as a barrier to expanding private market low-income housing construction.'

Whether the LIHTC requires good cause eviction is thus far unsettled. With the exception of one unpublished state appellate court decision, appellate courts have not weighed in on the issue. ${ }^{10}$ Instead, the debate has occurred primarily in local housing courts and between tenant advocates and the state housing finance agencies responsible for administering the LIHTC program. In a survey of these agencies, twenty-seven of the thirty-eight agencies that responded indicated that they do not believe that the federal LIHTC statute guarantees tenants of LIHTC subsidized units good cause eviction protection."

6 Throughout this Comment, "for cause" and "good cause" eviction are used interchangeably.

7 All but a few state landlord-tenant statutes allow no cause eviction; the landlord can terminate a tenancy at the end of a lease without explanation, so long as she gives the statutorily appropriate amount of notice. See notes 50-56 and accompanying text.

8 See, for example, Section 8 Housing Assistance Payments Program, Hearing before the Subcommittee on Housing and Community Development of the House Committee on Banking, Finance, and Urban Affairs ("Section 8 Hearing"), 103d Cong, 1st Sess 46 (GPO 1994) (statement of David B. Bryson, National Housing Law Project, Washington, D.C. on Nov 3, 1993) ("[Good cause eviction protection] serves to protect tenants against retaliatory and other arbitrary evictions from their home [sic]. For many tenants, it is an important safeguard against [ ] becoming homeless.").

9 See, for example, Robyn Minter Smyers, High Noon in Public Housing: The Showdown Between Due Process Rights and Good Management Practices in the War on Drugs and Crime, 30 Urban Law 573, 576,607-12 (1998) ("By the late 1980s, consensus was developing among [Public Housing Authority] and HUD officials, federal and state lawmakers, and tenants themselves that the procedural and structural changes wrought by the due process revolution were complicating efforts to make public housing a safe and decent place to live.").

10 Cimarron Village Townhomes, Ltd $v$ Washington, 1999 Minn App LEXIS 890 (holding that good cause eviction protection is provided for under the LIHTC statute).

11 The author conducted a telephone survey of all fifty state housing finance agencies charged with administering the LIHTC Programs. In each of the thirty-eight successful interviews, the author spoke to the official agency contact person for the program or to a person designated by that individual. Each interviewee was asked whether the agency requires that the extended use agreement (see note 30 and accompanying text) concluded with tax credit recipients include a provision that the current tenants of any units receiving an LIHTC subsidy will not have their tenancy terminated other than for good cause. In many cases, the author was able to review sample copies of the states' extended use agreements (sometimes called "sample land use restriction agreement").

Of the thirty-eight agencies successfully interviewed, twenty-seven reported not having 
Tenant advocates generally have not disputed this statutory interpretation. Instead, they tend to argue that the LIHTC program involves state action and that tenants are entitled to good cause eviction as a matter of constitutional due process. ${ }^{12}$ While there may be a due process argument for good cause eviction protection, this Comment argues that, contrary to dominant state agency practice, the LIHTC statute does require that tenants receive good cause eviction protection. A careful reading of Internal Revenue Code (IRC) Section 42 demonstrates that since 1990, in order to receive a tax credit, a landlord is required to place a restrictive covenant on her property that guarantees that tenants in her LIHTC subsidized units will not be evicted except for good cause.

Part I of this Comment provides a brief introduction to the LIHTC program through a discussion of the scope of the country's affordable housing crisis, the LIHTC's basic structure, and the extent of the program's success to date. Part II introduces the concept of good cause eviction, the doctrinal evolution of good cause eviction protection in federal housing programs, and the debate over the merits of the protection. Part III analyzes the LIHTC, arguing that the best reading of the statute's plain language, coupled with the limited available legislative history, leads to the conclusion that the LIHTC provides tenants with good cause eviction protection.

such a provision: Alabama, Alaska, Arkansas, Connecticut, Florida, Hawaii, Idaho, Illinois, Indiana, Louisiana, Maryland, Mississippi, New Hampshire, New Jersey, New Mexico, New York, Nevada, North Dakota, Ohio, Oregon, Pennsylvania, South Carolina, Texas, Utah, Vermont, Washington, and West Virginia. By contrast, Arizona, California, Delaware, Kansas, Massachusetts, Minnesota, Missouri, Nebraska, North Carolina, Virginia, and Wisconsin do include language guaranteeing current tenants good cause eviction protection. Jolin Telephone Survey (1999) (on file with author).

Because the question in this Comment has to do with how IRC Section 42 is interpreted by the state agencies, the author was not concerned with whether or not state landlord-tenant laws also provided good cause eviction protection, or with the fact that when LrHTC funds are combined with other federal housing program dollars (which often occurs) tenants typically receive good cause eviction protection. The author did not consider a global statement in an extended use agreement that the recipient must, for example, "comply with all requirements of IRC Section 42" to constitute inclusion of the good cause eviction protection. In addition to not satisfying what this Comment argues is a requirement that the protection be expressly stated in the extended use agreement, a global statement requiring compliance with Section 42 only begs the question in this Comment: What is the requirement of Section 42 with respect to good cause eviction?

12 The author has spoken to legal services housing attorneys in several states, as well as with low-income housing advocacy organizations familiar with the LIHTC. There was general agreement in these conversations that the LIHTC statute does not provide for good cause eviction protection and that constitutional due process arguments are the best alternative. 


\section{LIHTC:A PUBLIC-PRIVATE RESPONSE TO A GROWING AFFORDABLE HOUSING CRISIS}

At least since the mid-1980s, the supply of housing affordable to low-income households has increasingly fallen behind demand. While this housing crisis is not the result of any single cause, one important factor is the dramatic reduction in financial support for traditional federal low-income housing programs. The LIHTC program was created, in part, to make it financially feasible for private developers to build and maintain low-income housing and to help fill the void left by cuts in public housing and Section 8 rental subsidy programs. Through the allocation of tax credits to private developers-both forprofit and not-for-profit-the LIHTC has registered some significant successes. At the same time, the program has been subjected to substantial criticism from both liberals and conservatives. This Part addresses some of these important background issues in more depth.

\section{A. The Ongoing Rental Housing Crisis and Fading Federal Support}

The term "crisis" is an appropriate characterization of the circumstances facing low-income individuals in the rental housing market. According to the Center on Budget and Policy Priorities, between 1970 and 1993 the total number of low-cost rental units decreased from 7.4 million to 6.5 million, while the number of low-income renters demanding those units increased from 6.5 million to 11.2 million. ${ }^{14}$ The Department of Housing and Urban Development estimated that by 1995 , over 5.3 million households ( 12.5 million people) faced "worst case" housing needs, meaning they lived in seriously substandard housing (lacking basic systems such as plumbing and electricity) or paid over 50 percent of their income in rent. ${ }^{15}$ Despite persistent economic growth since the early 1990 s, conditions have continued to worsen. Between 1993 and 1995, 900,000 units affordable to "very lowincome" renters were lost. And between 1996 and 1998, the stock of rental housing affordable to "low-income" households declined by an additional 900,000 units. $^{16}$

13 For an explanation of the Section 8 subsidy program, see note 49.

14 Figures cited in John Atlas and Ellen Shoshkes, Saving Affordable Housing: What Community Groups Can Do \& What Government Should Do 78 (National Housing Institute 1997) (describing dire situation in public housing and noting that the " 4.7 million fewer low-cost rental units than low-income renters is the largest shortfall on record").

15 Department of Housing and Urban Development, Waiting in Vain: An Update on America's Rental Housing Crisis 1 (Mar 1999) ("HUD Rental Housing Report"). It is worth noting that the demographic group experiencing the greatest increase in worst case housing needs is working families. Between 1991 and 1995, the worst case housing need rose 24 percent among households with at least one full time minimum wage worker. Id at 2 .

16 Id at 1, 15. A "low-income family" is a family whose income does not exceed 80 percent of the median income for the area, and a "very low-income family" is a family whose income 
Throughout this housing crisis, the federal government has steadily reduced its overall financial commitment to low-income housing development and affordability. In 1981, the federal housing budget was $\$ 32.2$ billion. By 1989 , it amounted to only $\$ 7.9$ billion (less than 0.6 percent of the federal budget). ${ }^{17}$ During that same period, HUD reduced the number of new affordable units it helped construct annually from 144,000 to $22,000 .{ }^{18}$ The total number of additional households annually supported by HUD dropped by nearly half starting in 1984, and in 1995 no new rental housing vouchers were issued. ${ }^{19}$ Between 1994 and 1998, the total number of HUD supported households actually dropped by an estimated $65,000 .^{20}$ Since its creation in 1986 , the LIHTC program has offset some of this dramatic imbalance between availability and need by encouraging private actors to construct and manage new low-income units.

\section{B. LIHTC:A Supply-Side Subsidy Response to the Crisis}

In the 1980s, privatization became a popular policy prescription at all levels of government and for all sorts of government tasks. ${ }^{21}$ The Reagan Administration's President's Commission on Privatization identified low-income housing construction as a government service that ought to be privatized. ${ }^{22}$ Under President Reagan, the "federal government reduced direct federal housing spending while manifesting a view that the private sector, rather than the public sector, was better able to provide low-income housing."

does not exceed 50 percent of the median income for the area. 42 USC $\$ 1437 a(b)(2)$.

17 See Jonathan Klein and Lynne Wehrli, The Low-Income Housing Tax Credit: Federal Help for Low-Income Housing, 34 Boston Bar J 22, 22 (1990).

18 Id.

19 Between 1937, when the federal government first became involved in providing affordable rental housing, and 1996, the total number of HUD supported households-including those in public housing, those in Section 8 units, and those with Section 8 vouchers-grew to 4.3 million. HUD Rental Housing Report at 2-3 (cited in note 15).

20 Id at 16. Congress did appropriate 50,000 new Section 8 vouchers in 1998. Id at 4-5.

21 See Ronald A. Cass, Privatization: Politics, Law, and Theory, 71 Marq L Rev 449, 450-52 (1988) (noting that '“[p]rivatization,' a term rarely heard a few years ago, is now common around the world" and that "there frequently is consensus at an abstract level that it is good for private enterprise to do certain things and bad for government to do them"). For a discussion of the limits of municipal privatization efforts, see Rowan A. Miranda, Contracting Out: A Solution With Limits, in Terry N. Clark, ed, Urban Innovations: Creative Strategies for Turbulent Times 197, 20810 (Sage 1994) (concluding, from an empirical study, that contrary to the dominant theories provided by property rights theory and public choice theory, the greatest cost efficiencies (for cities contracting out services) were produced by contracts with non-profits and not by contracts with private, for-profit firms).

22 Green, 43 Cath U L Rev at 684 n 12 (cited in note 3).

23 David Philip Cohen, Improving the Supply of Affordable Housing: The Role of the LowIncome Housing Tax Credit, $6 \mathrm{~J}$ L \& Pol 537, 538 (1998) (noting the increasing trend toward privatization in low-income housing since the 1960s). 
some of the principles of privatization, but without giving up either federal or state regulatory control of the housing.

\section{The Technical Basics of the LIHTC Program}

Today, the LIHTC is the largest federal program that funds the construction and rehabilitation of low-income rental housing. ${ }^{24} \mathrm{Al}$ though the LIHTC imposes federal and state regulations on property owners similar to those that govern traditional United States Housing Act programs, it is structured very differently than other federal housing programs. The LIHTC is a federal low-income housing program that "attempts to employ market efficiencies while allowing states to impose local policy goals."

The LIHTC offers private entities, both for-profit and not-forprofit, a dollar-for-dollar tax credit for their investment in qualified low-income rental housing. ${ }^{26}$ The federal government annually allocates to each state a $\$ 1.25$ housing tax credit per citizen of the state. ${ }^{27}$ Each state designates an agency responsible for distributing the credits among applicants (a "housing credit" or "tax credit allocation" agency). ${ }^{28}$ Successful applicants receive credits based on the percentage of "the owner's basis in the rental units that are set aside for lowincome tenants." ${ }^{23}$ The credit recipient is entitled to write off a fraction of the credit from her personal or, as is more often the case, corporate income taxes each year for ten years, provided the units for which the credits were received remain in compliance with statutory and regulatory requirements. ${ }^{30}$ In order to receive tax credits, the building owner

24 GAO, Tax Credits at 2 (cited in note 2).

25 Jean L. Cummings and Denise DiPasquale, Building Affordable Rental Housing: An Analysis of the Low-Income Housing Tax Credit 4 (City Research Feb 1998), available online at $<$ http://www.cityresearch.com/lihtc/cr_lihtc.pdf> (visited Dec 26, 1999) (describing the basic nature and underlying purpose of the LIHTC program and introducing a detailed empirical study of LIHTC's effects over the past ten years).

26 IRC Section 42(g)(1)(A)-(B) provides that an eligible low-income housing project may either be one in which 20 percent of the units are rent restricted (to 30 percent of income) for tenants earning 50 percent or less of area median gross income, or one where 40 percent of the units are rent restricted (to 30 percent of income) and occupied by tenants earning 60 percent or less of area median gross income. See also IRC $\$ 42(\mathrm{~g})(2)(\mathrm{A})$ (defining rent restricted units).

27 IRC \$ 42(h)(3)(C)(i).

28 IRC $\$ 42(\mathrm{~h})(3)(B)$. The statute's term "housing credit agency" will be used interchangeably with "tax credit allocation agency" throughout this Comment.

29 Cohen, $6 \mathrm{~J} \mathrm{~L} \&$ Pol at 543 (cited in note 23). For the purposes of this Comment, it is not important to understand precisely how the credit amount is calculated. As the quote suggests, the credit amount depends in part on the number of units set aside for low-income housing. Other relevant factors include the amount invested in the building, whether the credit is for the purchase or rehabilitation of an existing building or for the construction of a new building, and whether another federal subsidy was used for the project. See Thomas R. Wechter and Daniel L. Kraus, The Internal Revenue Code's Housing Program: Section 42, 44 Tax Law 375, 376-77 (1991) (describing the criteria used to determine how the tax credit is computed).

30 "Although the credit is taken over a 10-year period, it is 'earned' over a 15-year 'compli- 
must agree to maintain the low-income units during a fifteen-year "compliance period" and must agree to an "extended use agreement" which typically requires that the units' low-income affordability be maintained for at least an additional fifteen years. ${ }^{31}$ In order to turn the tax credits into development capital, most developers sell the credits to investors at a substantial discount. ${ }^{32}$ These and other features of the program will be discussed in more detail in Part III.

While not sufficient to meet the growing demand for affordable rental housing, the LIHTC has achieved some noteworthy successes. ${ }^{33}$ A recent General Accounting Office study of the LIHTC found that between 1992 and 1994 state allocation agencies annually awarded tax credits with a value of $\$ 2$ billion over their ten-year duration. ${ }^{34} \mathrm{Al}$ though no exact count is available, estimates of the number of units placed in service between 1987 and 1996 range from 500,000 to 600,000 , and estimates through 1998 reach as high as $900,000 .^{35}$ Assuming that the figures for units put in service between 1994 to 1996 are representative, approximately three quarters of the households in these tax-credit supported units have incomes below 50 percent of area median income, and therefore qualify as "very low-income" by HUD's standards.

ance period.' If a low-income building is disposed of or converted to fair market use during the 15-year compliance period, the taxpayer is required to 'recapture' the unearned portion of the credit taken." Wechter and Kraus, 44 Tax Law at 399 (cited in note 29).

31 Id at 401-02 (explaining that "[f]or credits granted after 1989, a property will qualify for the low-income housing tax credit only if the taxpayer enters into an extended use commitment" that extends the low-income occupancy of the project for a minimum of fifteen additional years beyond the close of the fifteen-year low-income compliance period). See also IRC $\S 42(\mathrm{~h})(6)(\mathrm{A})-(\mathrm{B})$ for a definition and the requirements of an extended use agreement.

32 See note 38.

33 See Cummings and DiPasquale, Building Affordable Rental Housing at 36 (cited in note 25) (describing the increase in participation by private investors, state and local officials, and non-profit organizations in projects to provide low-income housing and highlighting the flexible nature of the LIHTC program).

34 GAO, Tax Credits at 2, 4 (cited in note 2). It is worth noting that the mortgage interest deduction, a homeowner tax credit, cost the federal government an estimated $\$ 58$ billion in 1995. Of that amount, an estimated $\$ 29$ billion went to households with incomes over $\$ 100,000$. See Peter Dreier, The GOP's Cynical Attack on Public Housing 3 (National Housing Institute 1996), available online at $<\mathrm{http} / / / \mathrm{ww}$.nhi.org/policy/gopatt.html $>$ (visited Jan 27,2000).

35 Cummings and DiPasquale, Building Affordable Rental Housing at 8 (cited in note 25) (describing the volume of the LIHTC program in the 1990s and summarizing past estimates of the program's growth before offering new data on this issue). See also Low Income Housing Tax Credit, 105th Cong, 2d Sess, in 144 Cong Rec S 12577 (Oct 14, 1998) (statement of Senator Alfonse D'Amato) ("The credit has been responsible for almost 900,000 units of housing in the past decade. Nearly all new affordable housing today ( $98 \%)$ is constructed with the help of the credit.").

36 GAO, Tax Credits at 6 (cited in note 2). 


\section{A Politically and Academically Contentious Program}

Despite its successes, the value of the LIHTC is contested among politicians, academics, and advocates. As recently as 1996, the Republican-controlled Congress sent a budget bill to President Clinton that would have eliminated the LIHTC. President Clinton, whose administration has strongly supported the program, vetoed the bill, citing the LIHTC as one reason. ${ }^{37}$ While the program is generally supported by moderates and progressives in the academic community, many of the LIHTC's most vocal critics are on the left. Some object to the heavy emphasis on a program they say is economically inefficient and cannot begin to meet the growing need for low-income housing. ${ }^{35}$ And most importantly for purposes of this Comment, tenant advocates complain that the LIHTC appears to have abandoned the right to good cause eviction enjoyed by tenants of traditional federal housing programs. Although not previously documented systematically, tenant advocates know from firsthand experience that many state housing credit agencies do not condition receipt of a tax credit on landlords providing LIHTC tenants with good cause eviction protection. ${ }^{39}$

The argument that state housing credit agencies' failure to provide good cause eviction protection is inconsistent with the statutory language of the LIHTC is the subject of Part III. But before commencing an analysis of the statute, we must be clear on what good cause eviction is and why it matters whether the LIHTC provides it.

37 In his veto of the 1995 Budget Reconciliation Bill, President Clinton cited the elimination of the tax credit as one reason for his veto: "Moreover, the bill would eliminate the lowincome housing tax credit and the community development corporation tax credit, which address critical housing needs and help rebuild communities." Seven-Year Balanced Budget Reconciliation Act of 1995-Veto Message from the President of the United States, 141 Cong Rec H 14136, 14137 (Dec 6,1995).

38 Analysts argue that the LIHTC program is less productive than reported because it displaces units that the market would otherwise produce. The program has produced far fewer units than needed to meet the needs of even very low-income families, and it is not clear that it has produced the kinds of units most needed by low-income families (for example, providing an appropriate number of bedrooms). Cohen, $6 \mathrm{~J} \mathrm{~L} \mathrm{\&} \mathrm{Pol} \mathrm{at} \mathrm{550-51} \mathrm{(cited} \mathrm{in} \mathrm{note} \mathrm{23).} \mathrm{Because} \mathrm{of} \mathrm{the}$ manner in which affordability is calculated in the program, most units are also unlikely to be affordable to the neediest households. Id at 552-54. The inefficiency of the credit stems, in part, from the overhead costs of administering the program and the substantial transaction costs associated with the distribution of the credits. Id at 557-58. In addition, developers typically sell their allocated tax credits to syndicates or large corporate investors at a discount. The buyer will pay considerably less than a dollar for each dollar write-off because only a fixed percentage of the total credit can be written off during each of ten years, and there is a risk that if the units cease to comply with affordability restrictions during the thirty year compliance and extended use period, a portion of the credit will have to be returned. As a result, for each dollar in federal tax subsidy, developers receive substantially less than a dollar in up front equity. Id at 557.

39 The author worked for the housing section of Legal Services in Portland, Oregon during 1997. Attorneys in that office related that they and their colleagues in offices around the country were defending a growing number of LIHTC tenants against no cause evictions brought under state landlord-tenant laws. 
To this end, Part II provides a brief history of good cause eviction, its evolution in federal housing programs, and a survey of the current debate over the merits of good cause eviction protection.

\section{GOOD CAUSE EVICTION: FROM COMMON LAW TO FEDERAL REGULATION}

At common law, there were three types of landlord-tenant estates: an estate for years, a periodic tenancy (year to year, month to month) and a tenancy at will. ${ }^{40}$ While they differed in terms of duration and notice requirements prior to lease termination, all three estates had in common that once the lease term expired either party could terminate the tenancy "for any reason or for no reason."

It is no longer the law in any state that either party can terminate a lease upon its expiration for any reason or no reason at all. The federal Fair Housing Act ${ }^{42}$ and the virtually universal state law prohibitions against retaliatory evictions place limits on the reasons a landlord may use to terminate or refuse to renew a lease. ${ }^{43}$ Good cause eviction is a similar, though much less common, restraint on a landlord's ability to evict at will.

\section{A. The Due Process Origin of Good Cause Eviction in Federal Housing Programs}

Under a good cause eviction regime, a tenant may terminate tenancy at the end of a lease term for any reason, but the landlord must renew the lease unless she can demonstrate to the court a good cause for not doing so. Such causes typically include nonpayment of rent,

40 Ralph E. Boyer, Herbert Hovenkamp, and Sheldon F. Kurtz, The Law of Property: An Introductory Survey $\$ 9.1$ at $245-47$ (West 4th ed 1991) (describing the basic features of the three types of landlord-tenant estates).

41 Edward H. Rabin, The Revolution in Residential Landlord-Tenant Law: Causes and Consequences, 69 Cornell L Rev 517, 534 (1984) (contrasting the traditional rule on eviction under the common law with the modern federal and state statutes limiting the reasons for which landlords might evict tenants).

42 The Fair Housing Act, Pub L No 90-284, 82 Stat 83 (1968), codified at 42 USC $\S 3604$ (1994), prohibits adverse housing actions based upon race, religion, national origin, or sex.

43 Rabin, 69 Cornell L Rev at 534 (cited in note 41) (stating that the landlord's traditional common law right to evict tenants without explanation "has been limited in every state by the federal Fair Housing Act, which prohibits discrimination ... and in most states by the doctrine prohibiting retaliatory eviction"). Retaliatory eviction protection is guaranteed in most states, either by statute or court decision. Id. In a typical retaliatory eviction case, a landlord seeks to evict a tenant who complained to a local housing code authority about the landlord's maintenance of the unit. See, for example, Edwards v Habib,397 F2d 687,690 (DC Cir 1968).

44 Rabin, 69 Cornell $L$ Rev at 535 (cited in note 41). "Just cause" eviction protection has been extended to tenants who "(1) are protected by a rent control ordinance that has a just cause eviction provision, (2) live in government owned or subsidized housing, or (3) are subsidized tenants in privately owned housing." Id.

45 Id. 
causing substantial physical damage to a unit, housing subtenants in violation of the lease, and similar infractions. ${ }^{46}$ In federally subsidized housing programs, what constitutes good cause is defined in part by regulation, but is ultimately a "case by case determination by the [local landlord-tenant] courts.",

When local public housing authorities ("PHAs") were created in response to the United States Housing Act of $1937^{48}$ (to provide local administration for public housing programs ${ }^{49}$ ), they were subject only to state landlord-tenant laws. Until the 1960s, therefore, PHAs "enjoyed almost unchecked power to evict tenants." During this period, courts upheld no cause evictions, ${ }^{51}$ as well as evictions based on such infractions as out-of-wedlock births, ${ }^{52}$ adultery, the misbehavior of children," and other PHA-determined forms of "undesirability."

46 See, for example, NJ Stat Ann § 2A:18-61.1 (West 1999) (providing a long list of potential eviction reasons that satisfy the good cause requirement, for instance: failing to pay rent, disturbing the peace of other residents despite previous written notice, causing damage or injury to the property willfully or "by reason of gross negligence"). See also 24 CFR § 966.4(1)(2)(i) (1999).

47 Federal Housing Commissioner (HUD), Explanation of Good Cause Regulation, $\S 882.215(\mathrm{c})(2), 49$ Fed Reg 12215, 12233 (1984). For an example of a Section 8 lease provision conforming to federal good cause regulations, see S.B. Partnership v Gogue, 1997 SD 41, 562 NW2d 754, 755 (1997).

48 Pub L No 93-383, 50 Stat 888 (1937), codified as amended at 42 USC § 1437a(b)(6) (1994 \& Supp 1996) (defining the term "public housing agency").

49 For purposes of this Comment, "public housing programs" are those in which the housing units involved are publicly owned and ultimately under the direct control of locally chartered public housing authorities. "Section 8 " is a program named for its location in the U.S. Housing Act of 1937, 42 USC $\$ 1437 f$ (1994 \& Supp 1996). Section 8 units are privately owned. A Section 8 subsidy can either be attached to the unit itself through a contract between the owner and the local public housing authority, or it can be brought to the unit by a low-income tenant who has a Section 8 voucher. In both cases, the tenant pays rent up to 30 percent of her income and the federal government pays the remainder, up to a pre-established "fair market rent" for the unit. For a general description of these and other HUD programs, see Department of Housing and Urban Development, Programs of HUD (1993).

50 Smyers, 30 Urban Law at 581 (cited in note 9).

51 See, for example, Walton $v$ City of Phoenix, 69 Ariz 26, 208 P2d 309, 310-11 (1949) (holding that the local housing authority maintained the same rights and remedies as any other landlord in eviction matters); Columbus Metropolitan Housing Authority $v$ Simpson, 85 Ohio App 73, 85 NE2d 560, 561-62 (1949) (rejecting tenants' argument that they "cannot be evicted without some cause being shown other than the termination of the lease").

52 McDougal $v$ Tamsberg, 308 F Supp 1212, 1216 (D SC 1970) (holding that "a large number of illegitimate children, each by different men, is a factor which may be considered by the Housing Authority").

53 Johnson v New Rochelle Municipal Housing Authority, 39 Misc 2d 138, 253 NYS2d 39, 40 (Sup Ct 1964) (holding that a landlord need not promulgate a regulation banning adultery in order to use "illicit relations" as a basis for eviction).

54 Smalls $v$ White Plains Housing Authority, 34 Misc 2d 949, 230 NYS2d 106, 108 (Sup Ct 1962) (upholding tenant eviction without a hearing based on misconduct of children).

55 New York City Housing Authority $v$ Watson, 27 Misc 2d 618, 207 NYS2d 920, 922-23 (Sup Ct 1960) (Hofstadter dissenting) (objecting to the court's finding that a tenant may not challenge PHA's reason for eviction and upholding eviction of wife and four children on grounds that husband's incarceration made them "undesirable" tenants). 
PHAs were also able to use the threat of eviction to gain compliance with a host of often intrusive behavioral rules.

The era of unchecked PHA discretion came to an abrupt end with the Supreme Court's ruling in Goldberg $v$ Kelly. In Goldberg, the Court ruled that terminating a recipient's welfare benefits without providing the recipient with a pre-termination eligibility hearing constituted a violation of that person's due process rights. ${ }^{\text {ss }}$ The innovation in Goldberg was to treat a government benefit as property that the government could not deprive a person of without due process of law under the Fifth and Fourteenth Amendments.

Within a year, circuit courts extended the reasoning of Goldberg to the public housing context. In Escalera $v$ New York City Housing Authority, ${ }^{60}$ the Second Circuit held that " $[\mathrm{t}]$ he government cannot deprive a private citizen of his continued tenancy [in a public housing unit], without affording him adequate procedural safeguards even if public housing could be deemed to be a privilege." ${ }^{61}$ In 1973, the Fourth Circuit took the final step and held that due process required not only just procedures, but also a legitimate reason for terminating a tenancy. In Joy $v$ Daniels, ${ }^{62}$ the court held that for procedural protections to have meaning, good cause must be shown to justify the termination of tenancy, irrespective of the terms of the lease. ${ }^{63}$

Unlike under the common law regime, therefore, the landlord had to provide a reason to justify non-renewal of the lease, and the tenant had a right to challenge the stated grounds for termination. Courts expanded the constitutional due process requirements to other federal housing programs, including Section 8 and a variety of con-

56 Smyers, 30 Urban Law at 583-84 (cited in note 9) (citing original HUD sources detailing the use of eviction threats and other punishments to achieve compliance with monthly unit inspection rules, as well as rules regulating the activities of children and the maintenance of fences and lawns).

57397 US 254 (1970).

58 Id at $262-63$.

59 Smyers, 30 Urban Law at 587-88 n 72 (cited in note 9) ("Beginning with the landmark case of Goldberg $v$ Kelly ... the Supreme Court signaled its willingness to extend due process protection beyond traditional notions of property to cover public benefits such as welfare."). See also Goldberg, 397 US at 262-64 \& n 8 (noting that welfare benefits were a matter of "statutory entitlement" and that "[i]t may be realistic today to regard welfare entitlements as more like 'property' than a 'gratuity"').

60425 F2d 853 (2d Cir 1970).

61 Id at 861, citing Goldberg, 397 US at 262-63. In Caulder v Durham Housing Authority, $433 \mathrm{~F} 2 \mathrm{~d} 998$ (4th Cir 1970), the court affirmed that "[t] he 'privilege' or 'right' to occupy publicly subsidized low-rent housing seems to us to be no less entitled to due process protection than entitlement to welfare benefits which were the subject of decision in Goldberg." Caulder, 433 F2d at $1002-03$.

62479 F2d 1236 (4th Cir 1973).

63 Id at 1240-42 (finding that due process clause requires for cause eviction protection because recent housing legislation recognizes an "entitlement to continue occupancy until there exists a cause to evict other than the mere expiration of the lease"). 
struction and rental subsidy programs; and once the due process underpinnings of the protection were judicially established, good cause eviction language was incorporated into the regulations of all the major federal housing programs. ${ }^{64}$

Although both HUD and the courts have continued to adjust the scope of the good cause eviction protection, the fundamental premise that tenants can not be evicted without good cause has remained intact. By the time the LIHTC was enacted in 1986, however, privatization and deregulation were popular policy prescriptions and some scholars were blaming tenant eviction protections for the ills of federally subsidized housing projects. The following section outlines the debate over good cause eviction and demonstrates why it is of such concern whether the LIHTC provides for it.

\section{B. The Debate over Good Cause Eviction Protection}

Critics of good cause eviction protection attack it on several grounds. Some argue that tenant protections, like good cause eviction, raise the cost of low-income housing, reducing the units that can be built and maintained by a private entity with a given level of subsidy, thus hurting low-income individuals as a class. ${ }^{65}$ In the public housing context, good cause eviction protection is also blamed for the concen-

64 The judicial expansion of good cause eviction protection beyond public housing included Jeffries $v$ Georgia Residential Finance Authority, 678 F2d 919, 925 (11th Cir 1982) (requiring good cause eviction where tenant receives a rental subsidy under the Section 8 Existing Housing Assistance Payment program); Joy, 479 F2d at 1243 (holding that tenants of privately owned units receiving federal subsidies under Section 221(d)(3) of the National Housing Act, 12 USC $\$ 17151$ (d)(3) (1971), are entitled to due process protections); Green v Copperstone, Ltd, 28 Md App 498,346 A2d 686, 697 (1975) (holding that tenant of unit that received construction and financing subsidy under Section 236 of the National Housing Act, 12 USC $\$ \S 1715 \mathrm{z}-1$ et seq (1968), is entitled to good cause eviction protection); Christian v Silver Maples Ltd Dividend Housing Association, 1986 US Dist Lexis 27154 (E D Mich 1986) (finding state action under the Section 8 New Construction program, despite lack of direct government involvement in the eviction decision).

A typical example of how good cause eviction protection has been incorporated into federal housing programs as a result of these decisions is found at 24 CFR $\$ 966.4(1)(2)(i)$. This particular provision applies to Section 8 , Section 202, and a variety of other National Housing Act programs:

(2) Grounds for termination. (i) The PHA shall not terminate or refuse to renew the lease other than for serious or repeated violation of material terms of the lease such as failure to make payments due under the lease... or for other good cause.

65 See, for example, Lawrence Kolodney, Eviction Free Zones: The Economics of Legal Bricolage in the Fight Against Displacement, 18 Fordham Urban L J 507, 520-21 n 52, 55 (1991) (compiling law and economics critiques of government-imposed tenant protections and explaining why such protections are considered detrimental to low-income individuals as a class). See also Steven Gunn, Note, Eviction Defense for Poor Tenants: Costly Compassion or Justice Served?, 13 Yale L \& Pol Rev 385, 386 (1995) (explaining the reasoning of those who argue that through tenant protections like good cause eviction "poor tenants as a class may ultimately suffer a reduction in the supply of decent, affordable housing"). 
tration of poor people in public housing, ${ }^{66}$ the physical deterioration of publicly subsidized housing, and the physical dangers faced by lawabiding tenants. ${ }^{67}$ Granting tenants good cause eviction protection is said to be yet another example of "overvaluing the rights of individual tenants as compared to the rights of other tenants and the needs of their communities." $\$$

In recent years, these criticisms have led to federal legislative efforts to define what will constitute good cause and to streamline the public housing eviction process. There have also been efforts to significantly limit the availability of the protection. In 1988 Congress amended the United States Housing Act to require that public housing leases contain provisions stating that criminal activity affecting the health and safety of public housing residents committed by any tenant, member of a tenant's household, or guest "shall be cause for termination of tenancy." ${ }^{\circ 9}$ HUD interprets the statute as imposing strict liability on tenants for the actions of their household members and guests. ${ }^{20}$ In 1996 the Clinton Administration put public housing tenants on notice that PHAs will employ a "one strike and you're out policy" with respect to evicting tenants under the criminal activity provision." While these efforts to define legislatively what constitutes good cause for eviction have succeeded, legislative initiatives to limit the availability of the protection itself have failed so far. The "Public Housing Reform and Empowerment Act of 1995," for example, would have amended the Section 8 program to require good cause for eviction only during the term of the lease. ${ }^{2}$ The proposal was not adopted. A similar, but more far reaching, proposal in the Housing Opportunity and Responsibility Act of $1997^{73}$ also failed to pass.

66 Michael H. Schill and Susan M. Wachter, The Spatial Bias of Federal Housing Law and Policy: Concentrated Poverty in Urban America, 143 U Pa L Rev 1285, 1299 (1995) (asserting that the loss of PHA "freedom to select and evict tenants has contributed to the concentration of poverty within public housing").

67 Vince Lane, former Chair of the Chicago Housing Authority, articulated what might be considered a "communitarian" critique of tenants' rights: "The time [has come] where the ACLU and everyone else is going to have to recognize that the majority of residents in public housing have rights, as well as the wrongdoers." Quoted in Smyers, 30 Urban Law at 608 (cited in note 9).

68 Smyers, 30 Urban Law at 608 (cited in note 9).

6942 USC $\S 1437 \mathrm{~d}(1)(6)(1999)$. This statutory requirement was incorporated into federal regulations at 24 CFR $\$ 966.4($ (f)(12)(i) (1999).

70 Robert Hornstein, Mean Things Happening in This Land: Defending Third Party Criminal Activity Public Housing Evictions, 23 S U L Rev 257, 263-65 (1996) (noting that the courts are divided on whether evicting tenants on a strict liability theory is consistent with due process).

71 Remarks Announcing the "One Strike and You're Out" Initiative in Public Housing, 32 Weekly Comp Pres Doc 582 (Mar 28, 1996).

72 S 1260, 104th Cong, 1st Sess (Sept 19, 1995), in 142 Cong Rec S 136, 147-48 (Jan 10, 1996) (proposing an amendment to Section 8 housing assistance in Title II Section 201(o)(7)(E)).

73 HR 2, 105th Cong, 1st Sess (Jan 7, 1997) (proposing to replace current public housing 
The failure of efforts to eliminate good cause eviction protection altogether from federal housing programs may only be a grudging acknowledgment of the constitutional origins of this protection. On the other hand, Congress' failure to attempt to do away with the protection may be an acknowledgment of arguments made by proponents of good cause eviction that any costs are minimal and are significantly outweighed by the benefits of good cause eviction protection to lowincome tenants.

To the economic incentive arguments, for example, proponents dispute the impact of the protection on low-income housing investment and construction, or at least the significance of that impact. ${ }^{74} \mathrm{Ad}-$ vocates of good cause eviction argue that any costs incurred are warranted by the reductions in improper and costly (in human and financial terms) evictions. ${ }^{75}$ The blame assigned to good cause eviction protection for the problems in federally subsidized housing-whether the insufficient supply, the concentration of poverty, or the deterioration of safety-is viewed as a cynical effort to distract attention from the real sources of such problems: long-standing policies concentrating public housing in impoverished areas, racism, dramatic cuts in all kinds of federal housing and welfare programs, poor quality public schools, a low-wage economy, and the like.

Proponents also point out the critical benefits of for cause eviction protection. They argue that a no cause eviction regime is an invitation to improper discrimination, especially in a tight market for lowincome housing where there are many applicants for every unit. Arguing to protect the good cause eviction provision in the Section 8 statute, David Bryson of the National Housing Law Project testified before Congress that the provision "serves to protect tenants against

lease requirements without including any provision for good cause eviction protection in Title II Section 226).

74 For example, Nancy Bernstine of the National Housing Law Project testified before Congress that " $\mathrm{t}]$ he contention that good cause inhibits participation by landlords in Section 8 needs to be kept in perspective. Some form of good cause has been included in law since 1982. Even with the good cause requirement, many thousands of landlords have participated successfully in the Section 8 program." Public Housing Reform and Empowerment Act of 1995, Hearing on S 1260 before the Senate Committee on Banking, Housing, and Urban Affairs, 104th Cong, 1st Sess 56 (1995) (opening statement of Nancy Bernstine).

75 Gunn, Note, 13 Yale L \& Pol Rev at 419-20 (cited in note 65) (concluding, based on an analysis of represented versus unrepresented tenants in housing court, that "the landlords who suffered the greatest amount of eviction-related losses were those least entitled to collect rent").

76 See, for example, Florence Wagman Roisman, Intentional Racial Discrimination and Segregation by the Federal Government as a Principal Cause of Concentrated Poverty: $A$ Response to Schill and Wachter, 143 U Pa L Rev 1351, 1364-69 (1995) (rejecting the claim that good cause eviction policies have contributed to concentration of poverty in public housing and the physical deterioration of neighborhoods; pointing instead to federal, state, and local policies that segregated poor minorities into impoverished areas, and the effects of economic transformations on the opportunities of the urban poor). 
retaliatory and other arbitrary evictions from their home[s]." Similarly, in requiring landlord recipients of federal subsidies to show good cause for an eviction, the court in Green $v$ Copperstone Lt $d^{78}$ explained that "[t]o allow a quasi public landlord to evict upon expiration of a fixed term is to enable secret and silent discrimination." ${ }^{77}$

Because of the tightness of the low-income housing market, and the general vulnerability of low-income households, proponents of good cause eviction argue that any eviction has devastating consequences. For households living on the financial margins, eviction often means homelessness. ${ }^{80}$ To the extent that a no cause eviction regime allows "secret and silent discrimination," landlords can also exploit low-income tenants' vulnerability, forcing them to endure substandard housing conditions and other indignities, under the threat of eviction.

Many of the competing claims for and against good cause eviction turn on empirical issues that are beyond the scope of this Comment. What is clear is that all sides, including the current tenants of LIHTC units, have a lot at stake in whether the nation's largest lowincome housing construction subsidy program includes good cause eviction protection.

Given the criticism that good cause eviction has received in the literature, the emphasis by federal lawmakers on local control and federal deregulation at the time the LIHTC program was created, and the relative obscurity of the good cause eviction provision in the LIHTC statute, ${ }^{81}$ it is perhaps not surprising that large numbers of state housing credit agencies believe no such protection exists. These factors may also explain why tenant advocates have largely looked past the LIHTC statute and have relied instead on due process arguments to establish a good cause eviction right for LIHTC tenants. Nonetheless, as Part III demonstrates, a close reading of IRC Section 42 leaves little doubt that a good cause eviction right was created under the LIHTC statute in 1990.

77 See Section 8 Hearing (cited in note 8 ).

7828 Md App 498,346 A2d 686 (1975).

79 Id at 694, citing Caulder v Durham Housing Authority, 433 F2d 998 (4th Cir 1970). See also Joy v Daniels, 479 F2d 1236, 1242 (4th Cir 1973) (finding that to allow such a "silent and secret discrimination" would "emasculate" procedural safeguards owed to tenants under the Fourteenth Amendment and detailed in Caulder).

80 Nelson H. Mock, Note, Punishing the Innocent: No-Fault Eviction of Public Housing Tenants for the Actions of Third Parties, 76 Tex L Rev 1495, 1499 (1998) ("Many serious consequences flow from the eviction of a public housing tenant, including great difficulty in finding alternative housing. Evicted families are forced into homelessness or temporary housing in a shelter.").

81 See Part III. 


\section{THE STATUTORY INTERPRETATION CASE FOR GOOD CAUSE EVICTION PROTECTION IN THE LIHTC}

Whether or not the LIHTC guarantees good cause eviction protection to tenants is a question with ramifications for nearly a million low-income households, and the number is growing every year. A large percentage of state tax credit allocation agencies currently do not require landlords who receive low-income housing tax credits to put good cause eviction provisions in their tenant leases. ${ }^{\mathrm{s2}}$ More specifically, the agencies do not believe that IRC Section 42 requires them to include a good cause eviction provision in the "extended use agreements" that the agencies must enter into with each tax credit recipient. $^{83}$ This Comment contends that these agencies are mistaken in their interpretation of the statute. Read properly, the federal statute governing the LIHTC requires state housing credit agencies to obligate tax credit recipients, as a condition of receiving the credit, to guarantee their tenants good cause eviction protection.

This Part analyzes the relevant language of IRC Section 42 as it evolved through amendment over time. In addition to its plain language, the statute's legislative history and recent congressional committee analysis support the conclusion that the LIHTC requires good cause eviction protection. The argument in this Part is made largely without the benefit of case law. To date, only one state appellate court opinion has considered the statutory construction question raised here, and while the court's analysis is entirely consistent with this Comment's argument, the opinion is unpublished.

\section{A. The Tax Credit as Originally Codified}

The Low Income Housing Tax Credit is codified at Section 42 of the Internal Revenue Code. Since its enactment in 1986, the statute has undergone numerous amendments. There was no reference of any kind to the conditions for tenant eviction in the initial version of Section 42. There is also no evidence in the legislative history of the Omnibus Budget Reconciliation Act of 1986 that the issue was ever considered. A reference to good cause eviction first appears in a comprehensive 1989 amendment of the statute.

82 See note 11.

83 The "extended use agreement" is a restrictive covenant that is placed on the LIHTC recipient property that spells out what the property owner must do in order to remain in compliance with the LIHTC program and continue to receive the credit. These provisions are discussed in detail in the text accompanying note 89.

84 Cimarron Village Townhomes, Ltd $v$ Washington, 1999 Minn App LEXIS 890, *8 (holding that LIHTC provides tenants in low-income housing with for cause eviction protections not only on a limited basis, as claimed by landlord-defendants, but throughout the thirty-year period for which a developer must commit itself to comply with statutory conditions). 
B. The 1989 Omnibus Budget Reconciliation Act

In 1989, following an exhaustive review of the program by the Mitchell-Danforth Task Force on the Low Income Housing Tax Credit, the LIHTC underwent substantial amendment. Among the additions to the statute enacted by the Omnibus Budget Reconciliation Act of 1989 were the Extended Low-Income Housing Commitment ("ELIHC") and an unrelated requirement setting conditions for tenant eviction should an LIHTC property be foreclosed upon or otherwise removed from the LIHTC program prematurely.

The ELIHC was apparently a response to the Task Force's finding that the original fifteen-year "compliance period" did not sufficiently secure the long-term affordability of LIHTC units. ${ }^{\$}$ As enacted, the ELIHC conditioned receipt of a tax credit for any year after 1989 upon the credit recipient placing a restrictive covenant on the credited property. That covenant-referred to as the "extended use agreement"-was required to contain, among other things, a commitment that the fraction of low-income units in the property will not decrease for at least fifteen years after the original fifteen-year "compliance period" has ended." The ELIHC also provided that the commitments made in the extended use agreement could be enforced by prospective, current, or past tenants of LIHTC units in state court. The ELIHC requirements were codified at IRC Section $42(\mathrm{~h})(6)(\mathrm{B}) .^{*}$

In a separate subsection of the statute, the 1989 amendment created two exceptions to the minimum thirty-year extended use period: (1) transfer after fifteen years to another owner who will maintain the low-income units and (2) foreclosure." Under the foreclosure provision, the extended use period would terminate upon foreclosure.

85 Pub L No 101-239, 103 Stat 2106 (1989).

86 Report of Mitchell-Danforth Task Force on the Low-Income Housing Tax Credit, January 1989 (on file with U Chi L Rev).

87 IRC $\$ 42(\mathrm{~h})(6)(A)$ (requiring that "no credit shall be allowed by reason of this section with respect to any building for the taxable year unless an extended low-income housing commitment is in effect").

88 Report of Mitchell-Danforth Task Force at 3-4 (cited in note 86).

89 IRC $\$ 42(\mathrm{~h})(6)(\mathrm{B})(\mathrm{vi})$ (classifying the extended use agreement between the taxpayer and the housing credit agency as being a "restrictive covenant").

90 After the 1989 amendment, Section 42(h)(6)(B)(i) of the IRC specifically stated that the ELIHC restrictive covenant must "require[ ] that the applicable fraction [of low income units] for the building for each taxable year in the extended use period will not be less than the applicable fraction specified in such agreement." The ELIHC also required that the restrictive covenant include an affirmative statement "allow[ing] ... prospective, present, or former [lowincome] occupants of [an LIHTC] building ... the right to enforce in any State court the requirement and prohibitions of clause (i)." IRC $\S 42(\mathrm{~h})(6)(B)$ (ii).

91 IRC \$ 42(h)(6)(E)(i)-(ii).

92 IRC $\$ 42(\mathrm{~h})(6)(\mathrm{E})(\mathrm{i})(\mathrm{I})$. 
It was in relation to the potential early termination of an extended use period that the 1989 amendment introduced the concept of good cause eviction protection. IRC Section 42(h)(6)(E)(ii) was added and provides that:

(ii) The termination of an extended use period ... shall not be construed to permit before the close of the 3-year period following such termination-

(I) the eviction or the termination of tenancy (other than for good cause) of an existing tenant of any low-income unit, or

(II) any increase in the gross rent with respect to such unit not otherwise permitted under this section.

This provision extended, through the use of good cause eviction protection, the period of low-income occupancy following premature termination of an ELIHC.

Following the 1989 amendments, therefore, two relevant provisions were in place. First, under IRC Section 42(h)(6)(B), all LIHTC projects now required a restrictive covenant running with the property containing provisions that were to remain in force for no less than thirty years, some of which could be enforced by interested lowincome individuals in state court. Second, an exception was created under IRC Section 42(h)(6)(E), which allowed for early termination of an extended use period, subject to a three-year ban on eviction of low-income tenants in the absence of good cause. At that time, there was no express statutory connection between the contents of the covenant and the post-termination good cause eviction protection. This changed in 1990.

\section{The Omnibus Budget Reconciliation Act of $1990^{93}$}

The 1990 Budget Reconciliation Act made primarily "technical corrections" to the LIHTC. ${ }^{24}$ One of those technical amendments is particularly critical to this Comment's analysis. It states, simply: "Clause (i) of section $42(\mathrm{~h})(6)(\mathrm{B})$ is amended by inserting before the comma 'and which prohibits the actions described in subclauses (I) and (II) of subparagraph (E)(ii)'." ${ }^{\text {"s }}$ This apparently innocuous crossreference creates a significant change in the statute. Clause (i) of Section $42(\mathrm{~h})(6)(B)$ is the provision that spells out what commitments are contained in the restrictive covenant required by the Extended

Pub L No 101-508, 104 Stat 1388 (1990).

94 The amendments to the LIFTC were originally part of the Technical Corrections Act of 1990, HR 5454, 101st Cong, 2d Sess, in 136 Cong Rec H 7138 (Aug 3, 1990).

95 Pub L No 101-508, 104 Stat at 1388-506. 
Low Income Housing Commitment. That clause, as amended, now defines the ELIHC covenant as that covenant which

requires that the applicable fraction [of low-income units] for the building for each taxable year in the extended use period will not be less than the applicable fraction specified in such agreements, and which prohibits the actions described in subclauses (I) and (II) of subparagraph (E) (ii). ${ }^{*}$

The subclauses (I) and (II) of clause (E)(ii) cross-referenced by this provision are those originally introduced as part of the foreclosure exception added by the 1989 amendment. The critical subclause, subclause (I), forbids "the eviction or the termination of tenancy (other than for good cause) of an existing tenant of any low-income unit.",

There are two possible readings of IRC Section 42 following this 1990 amendment. First, it may be that the amendment to clause (6)(B)(i) was intended to incorporate clause (E)(ii) in its entirety into the ELIHC. ${ }^{\text {\% }}$ If so, the good cause eviction language in subclause (E)(ii)(I) would remain confined to circumstances of foreclosure and early termination of an extended use agreement." On this reading, after 1990, an ELIHC covenant, or extended use agreement, should contain a statement such as "In the event of the early termination of the

96 IRC $\$ 42(\mathrm{~h})(6)(\mathrm{B})(\mathrm{i})$ (emphasis added).

97 IRC \$ 42(h)(6)(E)(ii)(I).

98 This appears to be the interpretation offered by the defendant landlords, and rejected by the court, in the only available opinion construing the relevant language of Section 42, Cimarron Village Townhomes, Ltd v Washington, 1999 Minn App LEXIS 890 at*4-7.

99 By reference, the amendment would incorporate both clauses (E)(i) and (E)(ii). The provisions are as follows:

(E) Exceptions if foreclosure or if no buyer willing to maintain low-income status.

(i) In general. The extended use period for any building shall terminate

(I) on the date the building is acquired by foreclosure (or instrument in lieu of foreclosure) unless the Secretary determines that such acquisition is part of an arrangement with the taxpayer a purpose of which is to terminate such period, or

(II) on the last day of the period specified in subparagraph (I) if the housing credit agency is unable to present during such period a qualified contract for the acquisition of the low-income portion of the building by any person who will continue to operate such portion as a qualified low-income building.

Subclause (II) shall not apply to the extent more stringent requirements are provided in the agreement or in State law.

(ii) Eviction, etc. of existing low-income tenants not permitted. The termination of an extended use period under clause (i) shall not be construed to permit before the close of the 3-year period following such termination

(I) the eviction or the termination of tenancy (other than for good cause) of an existing tenant of any low-income unit, or

(II) any increase in the gross rent with respect to such unit not otherwise permitted under this section. 
extended use period, current low-income tenants shall not be evicted for three years except for good cause."

The alternative and more appropriate reading of the amended statute is that clause (6)(B)(i) now incorporates into the restrictive covenant only the actions specifically spelled out in subclauses (6)(E)(ii)(I) and (II). In addition to providing for no reduction in the fraction of low-income units during the extended use period, the ELIHC covenant must now prohibit "the eviction or the termination (other than for good cause) of an existing tenant of any low-income unit." As a matter of statutory construction and legislative history, this reading is the superior one.

\section{Plain language and statutory construction.}

When interpreting a federal statute, the paramount objective is to determine the intent of Congress, and that intent is to be derived from the language and structure of the statute whenever possible. ${ }^{100}$ Thus, the starting point for interpreting the statute is the language itself, and unless there is clearly stated legislative intent to the contrary, the plain meaning of the language is determinative. ${ }^{101}$ In this case, our reading of the statutory language must also be guided by the rules of construction Congress has provided for the Internal Revenue Code. ${ }^{102}$

The plain language of the relevant statutory provisions, as amended, suggests that only the good cause eviction language of subclause (E)(ii)(i) is to be incorporated into the extended use agreement. The new language in (6)(B)(I) calls for an ELIHC covenant "which prohibits the actions described in subclauses (I) and (II) of subparagraph (E)(ii)." It is not a natural reading of this statement that the covenant is to include all of subparagraph (E)(ii). Nor would a literal reading incorporating all of (E)(ii) make sense. If the "action" which is to be prohibited is that which is described in (E)(ii), the covenant would prohibit " $[t]$ he termination of an extended use period" following foreclosure, from "not be[ing] construed to permit" the actions under subclauses (I) and (II). The covenant would thus impose an affirmative duty to construe foreclosure as permitting no cause eviction. Such an outcome would be absurd.

100 United States $v$ Lanier, 520 US 259, 267-68 n 6 (1997) (noting that the plain meaning of a statute is derived first and foremost from its language and not from "the assertions of codifiers directly at odds with clear statutory language").

101 Albernaz $v$ United States, 450 US 333, 338, 343-44 (1981) (relying on the plain language of a statute to conclude that the government may, without offending principles of double jeopardy, impose separate and consecutive penalties on offenders who violate two different statutes while engaged in a single conspiracy).

102 IRC \& 7806(b) (1999). 
By contrast, the proposed reading seamlessly integrates the text of (6)(B)(i) with the text of (E)(ii)(I) and (II). First, subclauses (I) and (II) each clearly contain "actions" which it makes sense to prohibit. Integrating the actual words, the ELIHC covenant shall be one "which prohibits" "(I) the eviction or the termination of tenancy (other than for good cause)" and "(II) any increase in the gross rent ...." The integration makes perfect sense without reference to the preceding language in (E)(ii). Based simply on a natural reading of the plain language, one can infer that Congress intended with its 1990 amendment to create good cause eviction protection for existing tenants.

This conclusion is reinforced by an application of the rules of construction that Congress has directed us to apply to the Internal Revenue Code. As the Minnesota court of appeals stated in Cimarron Village Townhomes, Ltd $v$ Washington, ${ }^{103}$ reading the post-1990 LIHTC statute as incorporating only subclauses (E)(ii)(I) and (II) into the extended use agreement is consistent with the IRC rule of construction that states "No inference, implication, or presumption of legislative construction shall be drawn or made by reason of the location or grouping of any particular section or provision or portion of this title."

This rule suggests that it would be inappropriate to assume that Congress intended to include, via cross-reference to a specific subclause, the terms of an entire clause. "The language of Section 42(h)(6)(B)(i) ... does not state "which prohibits the actions described in subparagraph (E)(ii).' We must, therefore, ... read subclauses (I) and (II) alone without any of the prefatory language of subparagraph (E)(ii).

Thus, under both general canons of statutory construction and the Internal Revenue Code's own rules of interpretation one must conclude that Congress intended to provide good cause eviction protection, unless there is a clear statement of legislative intent to the contrary. There is no such legislative statement. What little legislative history exists, supports the reading proposed here.

\section{Legislative history.}

The legislative history of the 1990 amendment is sparse. However, one specific reference to the relevant provision supports the reading proposed here. The crucial amendment was originally introduced as

\footnotetext{
1031999 Minn App LEXIS 890, *5-6.

104 IRC \$ 7806(b).

105 Cimarron, 1999 Minn App LEXIS 890 at *5-6.
} 
part of the Technical Corrections Act of $1990 .^{106}$ The Congressional Record explains the (6)(B)(i) amendment as follows:

The bill clarifies that the extended low-income housing commitment must prohibit the eviction or termination of tenancy (other than for good cause) of an existing tenant of a low-income unit or any increase in the gross rent inconsistent with the rent restrictions on the unit."

There is nothing in this language or elsewhere in the bill report suggesting that the prohibition on no cause eviction applies only to situations in which the extended use period is prematurely terminated through foreclosure. Instead, this paragraph seems clearly to state that Congress's intent in amending IRC Section 42(h)(6)(B)(i) was to extend good cause eviction protection to all tenants in LIHTC subsidized units.

The conclusion that good cause eviction protection is required by the LIHTC is reinforced by the most recent available congressional interpretation of the statute. In a 1997 report prepared by the staff of the Joint Committee on Taxation, the following statement was made with respect to what must be included in an Extended Low Income Housing Commitment pursuant to the statute:

The agreement must be recorded, pursuant to State law, as a restrictive covenant against the property.... It must allow any prospective, present, or former tenant the right to enforce the agreement in any State court. It also must provide that no existing low-income tenant may be evicted other than for good cause, and prohibit increases in gross rent above that which is otherwise allowable under Code section $42 .{ }^{103}$

This summary of what must be included in an extended use agreement is entirely consistent with the reading of the statute proposed here. There are no qualifying statements surrounding this quote that would suggest that good cause eviction protection is limited to the early termination of extended use periods.

\section{Potential objections.}

As clear as the text of the statute and the limited legislative history are, there remain objections that might be raised. The first is an argument about plausibility. Is it likely that an issue as politically sali-

\footnotetext{
106 HR 5454, 101st Cong, 2d Sess, in 136 Cong Rec H 7138 (Aug 3, 1990).

107 Id at H 7143. See also, Cimarron, 1999 Minn App LEXIS 890 at *7 (citing the same language from a report of the Joint Committee on Taxation).

108 Joint Committee on Taxation, Present Law and Legislative Background Relating to the Low-Income Housing Tax Credit (JCX-13-97R) 11 (Apr 30,1997) (emphasis added).
} 
ent as good cause eviction protection would be established in a "technical amendment," apparently without public debate, and through a relatively cryptic cross-reference?

The doctrinal answer to this objection is that, likely or not, the text is unambiguous and there is no clear statement of legislative intent to the contrary. ${ }^{109}$ Moreover, the evolution of the statute suggests that Congress may have taken for granted that good cause eviction protection would apply to a federal housing subsidy program like the LIHTC.

As discussed in Part II above, good cause eviction protection continues to be a virtually universal regulatory requirement of federal housing programs. Had Congress intended to abandon the protection completely, some statement to that effect would surely have been made when the program was first created. Instead, the issue was never addressed. It was not until after the 1989 amendment to the statute that Congress was forced to make its intent with respect to good cause eviction explicit. The 1989 amendment's explicit provision for good cause eviction protection in the event of foreclosure created the plausible argument that Congress's failure to provide expressly for the protection in other circumstances signaled Congress's intention not to do so. To avoid this conclusion, Congress passed a "technical amendment" to the statute in 1990 which clarified its original assumption that good cause eviction protection would be provided under the LIHTC. By relying on the simple cross-reference and not attempting to define the scope of that protection legislatively, Congress may have intentionally sought to avoid the political difficulties that would have resulted from a more expansive statement of this tenant protection in the statute. As written, Congress has simply left the task of defining the scope of the good cause protection under the LIHTC up to the IRS and the courts. This is admittedly only a plausible interpretation of the sequence of events that produced the current statutory language, but the lack of more extensive legislative history makes it impossible to do more than offer plausible speculations as to Congress's decisionmaking process.

The second objection that one might raise against the plain text reading of IRC Section 42 offered here is that when viewed in light of other federal statutory statements of good cause eviction protection, the apparently plain language of IRC Section 42 becomes ambiguous. Why, if Congress intended to create the right, did it not use the language common in other federal housing program statutes? As it hap-

109 Compare Cimarron, 1999 Minn App LEXIS 890 at *6 ("Because we find that the meaning of the statute at issue is unambiguous, we need not consider the legislative history of the statute."). 
pens, an amendment to IRC Section 42 was introduced in 1993 that would have allowed Congress to do just that, but it was never adopted. ${ }^{110}$ Furthermore, a report by the Joint Committee on Taxation explaining the proposed amendment concluded the "[Internal Revenue] Code [currently] do[es] not include any specific provisions concerning the grounds ... for termination of a tenancy." "If If one accepts upon this evidence that the plain text of the statute is, in fact, ambiguous, it might further be argued that the state tax credit allocation agencies' interpretation of the statute as not providing good cause eviction protection is entitled to deference by the courts.

While this argument cannot be dismissed out of hand, it is sufficiently weak that it poses no real danger to the statutory interpretation offered above. There are several reasons discussed above in this Part for why Congress might have chosen not to be more detailed in its statement of the good cause eviction protection. Perhaps Congress took the existence of the right for granted and sought only to make the assumption explicit. Or perhaps, as it often does, Congress chose to leave it to the IRS or the courts to provide a more detailed and context-specific definition of the right."

Although in some cases Congress has provided more exhaustive statutory statements of the good cause eviction protection, it is not the case that the LIHTC is unique in its relatively terse articulation of the right. For example, HUD's Section $1490 \mathrm{~m}$ grant program to replace and maintain affordable rural housing states: "(1) Assistance under this section may be provided ... only if - ... (D) the owner agrees to enter into and abide by written leases with the tenants, which leases shall provide that tenants may be evicted only for good cause." ${ }^{\text {113 }}$ The statute provides no further elaboration of the right. Furthermore, the

110 The proposed amendment would have added the following language to IRC Section 42:

(1) an applicant may not be denied admission to a low-income housing tax credit project because the applicant holds a voucher ... under Section 8 of the Housing Act of 1937; (2) no owner of a low-income housing tax credit project shall terminate a tenancy or refiuse to renew a lease of a tenant except for serious or repeated violations of the terms of the lease, for violations of the law or for other good cause.

Joint Committee on Taxation, Description of Miscellaneous Tax Proposals Scheduled for Hearings Before the Subcommittee on Select Revenue Measures of the House Committee on Ways and Means, JCS-8-93, 103d Cong, 1st Sess 131 (June 16,1993) (emphasis added).

111 Id.

112 Dombrowski $v$ Swiftships, Inc, 864 F Supp 1242, 1247 (S D Fla 1994) (explaining that when Congress uses terms that are vague, it is often true that "the boundaries of the standard are deliberately unclear to provide judicial flexibility").

11342 USC $\$ 1490 \mathrm{~m}$ (e)(1)(D) (1994). See also 12 USC $\$ 4108$, which provides that HUD may only allow federally subsidized building owners to escape their obligations to maintain lowincome units through a mortgage buyout if HUD makes a written finding that the buyout will not "involuntarily displace current tenants (except for good cause)..." 12 USC \$ 4108(a)(1)(B) (1994). 
simple fact that the language chosen by Congress leaves the boundaries of the right undefined does not make the statutory language ambiguous. A statute is ambiguous when "[i]t leaves the reader with at least two, apparently inconsistent, alternatives each of which, taken alone, seems free of ambiguity and appears to be meaningful." ${ }^{114}$ There is no plausible way to read the phrase "prohibits the eviction or the termination of tenancy (other than for good cause)" as allowing for no cause eviction. And as Part III.C.1 demonstrated, given the common meaning of the words used, the need for proper syntax, and the IRC's rules of interpretation, there is no plausible alternative to reading Section $42(\mathrm{~h})(6)(B)(\mathrm{i})$ as prohibiting only the specific actions in subclauses (I) and (II) of Section 42(h)(6)(E)(ii).

It is true that courts have held that "even where the language of a statute is superficially clear, legislative history may call such apparent clarity into question." "115 The two pieces of legislative history potentially in conflict with the reading offered here, however, do not have this effect. First, the most, if not only, relevant piece of legislative history for purposes of statutory interpretation is that written at the time the relevant language was enacted. ${ }^{116}$ In this case, that legislative history, cited in full above, is entirely consistent with the proposed plain language reading. ${ }^{117}$

Second, the fact that an amendment was introduced and defeated that would have provided expansive good cause language in the LIHTC does not clearly signal congressional intent not to provide the protection. This action is equally consistent with a congressional determination to leave the definition of the provision to the IRS or the courts. There is simply no legislative history on the proposed amendment that would allow us to determine which interpretation is more accurate.

The language in the Joint Committee on Taxation report that accompanied the amendment is a legislative interpretation of an existing statute and is of limited significance at best in determining Congress's intent in enacting the relevant statutory provision. ${ }^{118}$ Furthermore, as quoted earlier, the most recent Joint Committee on Taxation interpretation of the identical LIHTC statutory language concluded that tax

114 Dombrowski, 864 F Supp at 1247 (citing the Oxford English Dictionary).

115 American Scholastic TV Programming Foundation v FCC, 46 F3d 1173, 1180 (DC Cir 1995) (internal quotations omitted), citing Tataranowicz v Sullivan, 959 F2d 268, 277 (DC Cir 1992).

116 Sullivan v Finkelstein, 496 US 617, 631-32 (1990) (Scalia concurring in part) (rejecting credence given by the majority opinion to respondent's argument based on post-enactment legislative committee interpretation of a disputed statutory provision).

117 See text accompanying note 107.

118 Sullivan, 496 US at 632 (Scalia concurring in part). 
credit recipients must provide good cause protection for all existing low-income tenants.

It is worth noting in conclusion that even if a court were to agree that the statutory language is ambiguous, current state agency interpretations of the federal statute would most likely not be entitled to the kind of deference given federal agencies under Chevron.$^{120}$ This issue ought never to arise, however, since there is no basis for rejecting the plain language reading of the statute offered here.

\section{CONCLUSION}

While reading IRC Section 42(h)(6)(B)(ii) to require good cause eviction protection during the extended use period may not be popular with some, and while it will require a significant change in practice by many state tax credit allocation agencies, it is clearly the best reading of the statute. The reading is supported by the limited legislative history of the statute and the one judicial opinion available on the issue. While there is evidence against the reading, that evidence is inconclusive, at best, and cannot overcome the plain language of the statute. That language requires all low-income housing tax credit recipients to place a restrictive covenant on the tax credit property, and that covenant must contain a provision guaranteeing tenants a good cause eviction right enforceable in state court.

119 See text accompanying note 108.

120 Chevron, USA, Inc v Natural Resources Defense Council, Inc, 467 US 837 (1984) (holding that where Congress's intent is not unambiguously expressed in a statute in light of common canons of construction, courts should give deference to a reasonable interpretation of the statute by the federal agency in charge of administrating the statute at issue). Several circuits have held either that state agency interpretations are not entitled to Chevron deference, or that they are only entitled to Chevron deference if the interpretation is expressly approved by a federal agency. Orthopaedic Hospital v Belshe, 103 F3d 1491, 1495 (9th Cir 1997) ("A state agency's interpretation of federal statutes is not entitled to the deference afforded a federal agency's interpretation of its own statutes under Chevron."); Amisub (PSL), Inc v Colorado Department of Social Services, 879 F2d 789,795-96 (10th Cir 1989) (subjecting state Medicaid plan to de novo review because "[t] with federal law is not entitled to the deference afforded a federal agency"); Turner $v$ Perales, 869 F2d 140, 141 (2d Cir 1989) (holding that state regulations implementing federal statute are subject to de novo review and are not entitled to Chevron deference); Perry v Dowling, 95 F3d 231, 236-37 (2d Cir 1996) (distinguishing Turner and holding that where "the state has received prior federal-agency approval to implement its plan, the federal agency expressly concurs in the state's interpretation of the statute, and the interpretation is a permissible construction of the statute, that interpretation warrants deference"). It should be noted that the Internal Revenue Service has not so far issued any interpretation of the statutory provisions under consideration in this Comment. 